\title{
Long Nav or Short Nav?: Student Responses to Two Different Navigational Interface Designs in LibGuides Version $2^{\text {is }}$
}

\author{
Aaron Bowen $^{\mathrm{a}, *}$, Jake Ellis ${ }^{\mathrm{a}}$, Barbara Chaparro ${ }^{\mathrm{b}}$ \\ ${ }^{a}$ Wichita State University, 1845 Fairmount St., Wichita, KS 67260, United States \\ b Embry-Riddle Aeronautical University, 600 South Clyde Morris Blvd., Daytona Beach, FL 32114, United States
}

\section{A R T I C L E I N F O}

\section{Keywords:}

Usability

Usability testing

LibGuides

Library guides

Information literacy

\begin{abstract}
A B S T R A C T
This study used two successive phases of usability testing to evaluate two different versions of a Communication 430 course LibGuide. The first version of this guide had a longer, more visually complex navigation menu, with more course-related research information directly accessible through this menu. The second version had a shorter, less complex menu that offered less directly accessible information. Twenty-four of the 33 students enrolled in the class (73\%) tested either one version or the other for usability in completing tasks that simulate course-related research assignments, ultimately indicating they found the longer navigation menu more usable. This paper may be the first to describe the engagement of students enrolled in a course in testing a LibGuide dedicated specifically to that course. As such, it will be of interest to many academic librarians and instructional design professionals.
\end{abstract}

Inspired by increased interest among librarians from the 1970s onward in helping their patrons both access library resources and become information literate, many university libraries include research guides on their Web sites. With some exceptions, these guides are typically either course guides or subject guides - in other words, tailored to the research needs or assignments of an individual course, or to the research needs of a broad field of study. The content they present and architecture of how they present it may change accordingly. Though they are often created using the Springshare company's LibGuides software package, these guides are almost always designed or customized by individual librarians and tailored to individual courses and curricula at the university. Consequently, the questions of what to put on a guide and how best to arrange that material have driven an entire research agenda for the better part of a decade.

A typical course-based information literacy (IL) guide, including those discussed in this study, is designed to assist students in finding information for their coursework. Most librarians, however, do not believe that simply creating a guide to do this is enough. Most librarians make some amount of effort to design their guides to be user-friendly, or, to use another word, usable. As defined by the International Standards Organization (ISO 9241-11:1998), usability is the "extent to which a product can be used by specified users to achieve specified goals with effectiveness, efficiency and satisfaction in a specified context of use" (International Standards Organization, 1998). ${ }^{1}$ A usable guide accordingly fulfills the goal of assisting students in finding information for their class in several ways, such as situating the user's coursework needs in a broader research process, placing searchable sources of information in a context that ties in to these needs, and offering guidance on how best to utilize these sources to find the most targeted, relevant, and valuable information relating to these needs. Design measures to address these needs can help maximize student ability to search for and find information effectively and efficiently, and be satisfied the guide has thoroughly helped address their research needs.

This study compares the usability of two versions of the LibGuide developed for a Communication 430 (COMM 430) course based on multiple methods of usability testing. It attempts to answer this research question: Does the layout of a course guide's navigation menu affect the three aspects of usability drawn from the ISO's definition of usability? To answer this question, this study measures the following:

- Effective use of the resources and information presented in each navigation menu to assist students in completing course-related work

- Efficient use of the resources and information in each navigation menu to accomplish the same task

\footnotetext{
मे Declarations of interest: none.

* Corresponding author.

E-mail addresses: aaron.bowen@wichita.edu (A. Bowen), jdellis1@shockers.wichita.edu (J. Ellis), barbara.chaparro@erau.edu (B. Chaparro).

${ }^{1}$ An extended discussion on the definition of "usability" as a term, such as that offered in Chen, Germain, and Rorissa (2011), is outside the scope of this article.
} 
- Student satisfaction with the navigation menus in terms of clarity and ease of use

Answering this question will add valuable information to the body of literature on usability practices in guide design, as well as to the library community's understanding of the mental models their patrons follow when using guides to find information.

To investigate these variables within in each version of the COMM 430 guide, a usability test with a set of ten student testers was held in the Software Usability Research Lab (SURL) at Wichita State University, and an additional assessment with a set of 14 student testers was conducted online. These tests specifically focused on the left-side navigation menu of each version of the guide, as one version has a longer leftside navigation menu offering access to library resources and their related instructional materials, and the other version with a shorter menu offering access only to library resources, while using a third, ancillary guide to contain instructional materials. These two versions are hereafter referred to as the Long Version and the Short Version respectively.

The arrangement of these guides reflects a question posed by Sinkinson, Alexander, Hicks, and Kahn (2012): "Do users want a research guide that teaches them how to do something, or simply directs them to the appropriate source for completing a given task?" In this study, both versions of the course guide offer access to library resources and teach students how to use them, but the Short Version removes the instructional material to an ancillary guide in an effort to consolidate the amount of material students encounter when viewing this version.

While it wasn't an explicit focus of the research, this testing also revealed additional strengths and weaknesses of the overall usability of the guide. Studying these ideas helps update and improve underlying models that inform the contemporary design of library guides and their features, thus strengthening the overall perception of how guides may be designed for maximum usability.

\section{Constructivism, cognitive load theory, and their application to usability and user-centered design in LibGuides}

\section{Constructivism}

A rich history of pedagogical theories may be connected to information literacy broadly, and from there to the design and creation of course- or subject-specific guides. In particular, designers of library guides have largely shifted away from building upon theories that place library resources and the information retrieval systems that facilitate access to them at the center of the library's information space, and have instead adopted a model that places the person doing the searching at the center of that space. In practice, this shift has seen libraries design guides that draw from the patron-centered constructivist model as opposed to the retrieval-driven behaviorist model.

While behaviorist models, such as Ellis (1989), set many standards in understanding the information seeking, finding, and use process, what is largely missing in this work is an extensive examination of the environmental and patron-specific (which in a university environment means student-specific) factors that will affect this process. Environmental factors include university-specific elements, such as the number of libraries on campus, the number of computers they offer, the size of the library's physical, ebook, and database collections, and how librarians organize this material to make it accessible and useable to students. Student-specific factors include the courses they take and the curricula they follow during their time at the university, and the way(s) in which they construct learning experiences by accessing relevant scholarship through the library. The presence of these factors is often implied in behaviorist literature, but rarely receives explicit acknowledgement, let alone exploration.

In examining these environmental and student-specific factors, Kuhlthau (1991, 2004), Allen (1996), and Bruce (1997) looked past behaviorist models and instead focused on constructivist pedagogical theory, emphasizing the searcher as an active player in the search process. Constructivism has since been the major theory present in the literature on IL. Allen (2008), for example, offers an extensive article on this pairing, in which she charts the development of constructivism, and how it has enjoyed a natural pairing with IL instruction methods and tools, particularly in an online environment. Johnson (2007) discusses both behaviorism and constructivism in designing IL coursework. He argues that student learning is easier to curate when designing IL instruction using the behaviorist model (though he is careful to avoid arguing that students will necessarily learn more under this approach). By contrast, he argues that independent student learning is better reinforced under the constructivist model, through which students make their own discoveries of resources and information. This approach more naturally lends itself to learning opportunities afforded through online guides, where a librarian will have curated the guide design, but the students are from that point on responsible for understanding that design and using it to effectively and efficiently find information.

After charting the intellectual development of library pathfinders as they moved online and ultimately became IL guides, Hemmig (2005) ties constructivism to guide design. Drawing from Allen (1996) and Kuhlthau (1991), he advocates for making the patron the center of any model governing the design of library services, and then focusses on IL guides as a critical part of those services, in that they offer one of the main interfaces between a patron searching for (or learning how to search for) information and the vast array of information resources available in the library collection. He makes a constructivist understanding of information searchers an explicit part of his articulation of user-centered design by saying that, "We seek a model for the guide as an interaction or communication point between the user and the information service, defined by the service's available resources and by a multi-dimensional model of the user, including the user's situation in the [information search process] (Hemmig, 2005, p. 80)." Based upon this logic, he updates Saracevic's (1996) Stratified Interaction Model of information retrieval through automated library systems to include a stronger emphasis on the user's construction of the context in which s/ he is searching a library guide.

Following from this user-centered design focus, Hemmig (2005) argues that the measure of success of any library tool (of which a guide is one such example) is the patron's experience. If a patron is able to effectively and efficiently search for and access useful information through a library guide (or, more specifically, the database and metasearch tools presented via the guide), that student will likely describe the experience of using the guide as satisfactory or better. This makes the design of the guide and its elements - in the case of this study, navigational elements in particular - of paramount importance in ensuring the guide is usable to a patron base of university students.

\section{Cognitive load theory}

A separate theory that parallels this shift from behaviorism to constructivism is cognitive load theory, or CLT. CLT does not attempt to model how patrons may most effectively use a guide to search for information; as such it is a fundamentally different type of theory than the pedagogical theories discussed above. Rather, CLT stipulates that a guide should be as easy, clear, and intuitive for students to use as possible. Under such a design, the guide will not force them to expend extra thought understanding the guide itself, and instead dedicate that cognitive capacity to understanding the material they discover through the guide.

Both Allen (1996) and Ingwersen (1996) are mindful of the level of cognition a patron must expend in using an information retrieval system. Allen dedicates a portion of his discussion of patron information needs to cognition. Somewhat similar to Saracevic's (1996) Stratified Interaction Model, Ingwersen's Cognitive Information Retrieval Theory makes cognition the underlying ontology that mediates human and machine interaction in information retrieval. In this regard, 
Ingwersen's theory almost serves as a bridge between the level of cognition a patron requires to understand and use a guide, and how she or he constructs meaning from the scholarship discovered through using the guide - he approaches both CLT and constructivism without explicitly discussing either as part of his theory. Allen does the same, with a more explicit emphasis on user-centered design.

Little (2010) completes this bridge. In discussing how CLT can be applied to library guides in order to minimize the cognitive load required to use them, she argues that the intellectual organization of the material discovered through a guide, "must be constructed by the learner" (Little, 2010, p.54). She further elaborates on design strategies that can be employed to mitigate cognitive load in using guides. One such strategy is incorporating strong navigational elements into the design of the guide, under the logic that clear navigation around the guide will reduce the cognitive load needed to use it (thereby making it more usable).

In a similar analysis, Tempelman-Kluit (2006) connects both constructivism and CLT to information literacy. She focusses on online tutorials used in the delivery of Web-based instruction, and argues that these tutorials can lead to cognitive overload if they do not engage enough of the human senses in offering instruction and/or are not sufficiently modular in delivering their instruction. Jackson (2007, 2008) further develops the connection between IL and cognition. Most recently, Baker (2014) warns against inviting cognitive overload by including too much detail in LibGuide design, and both Grassian, LeMire, and German (2017) and Pickens (2017) tie cognitive load to user-centered design and apply both to LibGuides specifically.

Incorporating CLT into the design of a library guide, and thereby enabling the patron to minimize the cognitive effort required to use the guide, fits well with the measures set forth in the International Standards Organization's definition of usability. A guide that seeks to minimize the cognitive load required to use it should conversely maximize the effectiveness and efficiency with which it may be used. It will also likely maximize the chance that students are satisfied using the guide to find needed information.

\section{LibGuides}

Although a body of academic literature on LibGuides has developed since it was released, student use of LibGuides - particularly LibGuides Version 2, which was released in late 2014 - is still in significant need of study. In 2010, when LibGuides was three years old, literature describing the product and its implementation began to be published (Adebonojo, 2010; McMullin \& Hutton, 2010; Miner \& Alexander, 2010). Though less common now, studies of this nature do continue to appear (Collery, Collinge, \& O'Ceallaigh, 2016; Liébert \& Coig, 2015; Oelschlegel, Luhrs, \& Lindsay, 2017).

The first critical evaluations of the product's value in helping students conduct research were published in 2012 and have continued to be published since then, though they are still very much in a state of development. Mahaffy (2012) reported the results of two focus group conversations on how students used guides and what they would like to see on them. Bowen (2012) presents the first published instructions documenting how to embed a LibGuide into the BlackBoard learning management system (LMS), paired with a student evaluation of accessing their guide via BlackBoard. Murphy and Black (2013) follow up with their own study of student response to library guides in their LMS. Drawing from CLT, Baker (2014) advocates a need for IL tutorials done via LibGuides. Dalton and Pan (2014) respond by assessing their university's LibGuides in delivering IL instruction. Bowen (2014) evaluates student completion of an IL assignment presented as a LibGuide in comparison to the same assignment created as a series of Web pages. Adebonojo and Campbell (2017) and Chiware (2014) both document their process of developing assignments in LibGuides and soliciting feedback on the contribution the guides made to assignment completion. First Dobbs, Sittler, and Cook (2013) and then Dobbs and Sittler
(2016) and Sittler and Dobbs (2016) dedicated books to different aspects of designing useful and effective LibGuides.

Some of these articles cover the navigation elements of LibGuides, but only Thorngate and Hoden (2017) and Pittsley and Memmott (2012) make it the focus of their research. Reconfirming both Corbin and Karasmanis (2009) and Hungerford, Ray, Tawatao, and Ward (2010), Pittsley \& Memmott (2012) found that LibGuides Version 1's tabbed interface made finding library resources difficult when these resources are arranged across multiple tabbed pages on the guide. Furthermore, as Burrell \& Sodan (2006) found in 2006 and Thorngate \& Hoden (2017) reconfirmed in 2017, Web users have an easier time navigating a left-side menu. Springshare seems to have accepted this finding, and created a left-side menu-based navigational scheme in LibGuides Version 2.

While the community of librarians interested in LibGuides is moving beyond product descriptions and into critical evaluation of the product, many aspects of how students find, access, and use guides to conduct research are still open for exploration. As recently as 2015, Giullian \& Zitser (2015) were lamenting the scarcity of investigative research on LibGuides

\section{Usability and user-centered design in LibGuides}

A review of the literature also reveals little documentation of usability testing on LibGuides - a scarcity noted by Thorngate and Hoden (2017), who issue a call for further research.

Usability is a topic that has generated a voluminous body of literature, much of it written outside the library world, focusing on the usability and design of Web pages. Librarians have drawn from this body of literature to study library guides generally (Courtois, Higgins, \& Kapur, 2005; Sinkinson et al., 2012; Staley, 2007; Stitz, Laster, Bove, \& Wise, 2011; Tchangalova \& Feigley, 2008), and then LibGuides specifically (Ouellette, 2011; Glassman \& Sorensen, 2010; Gonzalez \& Westbrock, 2010, and, with only a passing reference, Hintz et al., 2010).

These studies describe how guides match design principles developed in the broad body of Web usability literature. Studies that apply actual usability testing to LibGuides, however, are less plentiful (Almeida \& Tidal, 2017; Conerton \& Goldenstein, 2017; Hernandez \& McKeen, 2015; Quintel, 2016; Sonsteby \& Dejonghe, 2013; Thorngate \& Hoden, 2017). ${ }^{2}$ Testing LibGuides for usability has further been the subject of multiple conference presentations (Markman, 2016; Alverson, Schwartz, \& Brunskill, 2015; DiSimio \& Chrisagis, 2014; Bazeley \& Natale, 2014; Turner \& Myer, 2012; Hungerford et al., 2010), as well as grey literature such as testing proposals and reports, and student assignments.

Thorngate \& Hoden, Almeida \& Tidal, Quintel, and Hernandez \& McKeen are the only studies that consider LibGuides Version 2. All researchers drew usability testers from at least two fields of study and had them test a broad range of guides across those developed at their respective universities. Cobus-Kuo, Gilmour, and Dickson (2013) is the only study to draw participants from a university course - and even then, the students in this course evaluated a range of subject and course guides designed with the SubjectsPlus software package.

The present research, accordingly, appears to be the first to document students within a university course offering their perspectives on using the LibGuide dedicated to their own course. ${ }^{3}$ The canon of works

\footnotetext{
${ }^{2}$ Two others, Cobus-Kuo et al. (2013) and Vileno (2010), engage in usability testing of guides not designed with LibGuides. Cobus-Kuo, Gilmour, and Dickson used SubjectsPlus. Vileno did not talk about the software used to create guides at her university, though her screenshots reveal it is not LibGuides.

${ }^{3}$ The course-specific nature of this research is particularly pertinent in light of Reeb and Gibbons (2004) now famous finding that students prefer course guides over subject guides. This finding has been a driving factor in guide design ever since, and has been upheld in subsequent literature, such as Castro Gessner, Chandler, and Wilcox (2015).
} 
on LibGuides usability testing demonstrates that, while testing has received discussion within the librarian community, documentation of that testing is still in a significant state of development, and additional contributions to this canon are valuable.

\section{The Communication 430 course guide at Wichita State University}

Within the curriculum designed by the Elliott School of Communication at Wichita State University, Communication 430: Communication Research and Inquiry (COMM 430) is the primary class designed to teach research and research methodology in the field of communications. Its description in the course syllabus is as follows:

[COMM 430] Introduces the process of research and inquiry across the discipline of communication. Helps students in communication become more intelligent consumers of research and investigative inquiry and to become more adept at designing their own research projects. Includes information gathering, structuring inquiry with qualitative and quantitative research designs and processing and reporting information.

Accordingly, the majority of students who take this course are majoring in one of the degree programs offered through the Elliott School.

To support the course's goals, the WSU University Libraries created a library guide for the course in LibGuides Version 2. This guide includes databases and other library resources useful for members of the class to complete their coursework, as well as information on using these resources.

During the summer of 2016, the authors developed two redesigns of the guide, the Long Version and the Short Version, for comparison. In keeping with the best practices established in library usability literature (Quintel, 2016; Sonsteby \& DeJonghe, 2013), some guide features were consistent across each redesign, such as the color of the tabs, having a site map or a table of contents on the home page of the guide, and having the librarian's image and contact information (Anderson \& Still, 2013). The main difference between the two redesigned versions is the left-side navigation each possesses.

The Long Version has a longer left-side navigation bar. This bar offers more resources and information within the guide's top level of navigation, but visually lengthens the menu of options to access that content. In addition to the navigation bar, the Home tab of the guide offers a hyperlinked site map of all the pages and sub-pages within the guide (see Fig. 1).

This Long Version offers access to both article and newspaper databases, the catalog, and demographic and statistical sources relevant to the course. It also offers access to information intended to help students effectively use these sources, such as pages offering tips on search strategies, on understanding the differences between scholarly and newspaper articles, and on composing a literature review.

The Short Version has a shorter left-side navigation bar, reducing the number of resources and amount of visual information at the guide's top level of navigation. Paralleling the first version, the Home tab of the second version of the guide offers a hyperlinked site map of all the pages and sub-pages within the guide (see Fig. 2).

This Short Version offers the article and newspaper databases, the catalog, and demographic and statistical sources, but removes the instructional information to an ancillary guide titled Communication Research Strategies (see Fig. 3).

In the Short Version, this ancillary guide is directly linked from a subtab titled "Strategies for searching for, evaluating, and citing articles you find," which appears under the Find Articles tab (see Fig. 2). The ancillary guide is also linked from a content box on both the "Find scholarly articles" and "Find newspaper articles" subtabs, which also appear under the Find Articles tab (see Fig. 4).

The idea behind having an ancillary guide is that instructional materials could all be maintained in one place, and course and subject guides could link to it as needed. If students found this architecture useable, it would afford librarians considerable flexibility in designing LibGuides to offer pathways to instructional content based upon course needs, while further affording them shorter navigation menu designs. For this architecture to be useable, however, these pathways would need to feel seamless to students using their course guide. It remained, however, an open question whether students would perceive them as such in the COMM 430 guide, or whether they would prefer instructional materials to be reproduced directly in a lengthened navigation menu in this guide, and potentially in different iterations (involving different content designed by different librarians, without a central point of curation) in their other course guides. Accordingly, the following research asks which of these two navigational architectures do COMM 430 students find most effective and efficient to use to complete their coursework, and which design offers the greatest level of satisfaction with the course guide in terms of ease and clarity of use.

\section{Overall methodology}

To measure the effective use, efficient use, and satisfaction with use of the Long and Short designs, this study employed two forms of usability testing, conducted in two successive phases. The first phase involved inviting ten students to participate in a usability test in Wichita State University's Software Usability Research Lab (SURL). The second phase involved a more informal appraisal using Optimal Workshop's Treejack software package to assess the intuitiveness specifically of the navigation of each version. Treejack is "tree testing" software, which removes all graphic elements from a webpage except for the navigation menu. As it tested only the navigational elements of each version, it is different from the formal usability test conducted in Phase One, which was more holistic in measuring student experience using the two versions.

Phase Two had 14 additional participants. The total number of usability testers was 24 of the 33 students enrolled in the class (73\%). There was no overlap between students who participated in each phase. Human subjects approval for each testing phase was obtained from Wichita State University's Institutional Review Board.

\section{Phase One methodology}

\section{Participants, materials, and procedure}

Ten participants (female $=8$, male $=2$ ) were recruited from the Fall 2016 COMM 430 class at Wichita State University to participate in the usability study of the two versions of the COMM 430 LibGuide. A between-groups single-factor design was used with five participants randomly assigned to one of two groups. Members of the first testing group evaluated the usability of the Long Version, and members of the second testing group evaluated the usability of the Short Version. Participation in this research study, while voluntary, was one of several activities a student could choose to fulfill the course requirements. Test participants completed a set of tasks representative of typical usage of the guide.

This testing was conducted in a private room in SURL on a Dell Precision T3600 computer running Microsoft Windows 7 and an AOC monitor with a $1920 \times 1080$ screen resolution. The testing employed a moderator to facilitate the tests and manually record test subjects' activity. Task success, difficulty ratings, confidence in task success, and participant comments were manually recorded within a spreadsheet.

Student activity to complete the tasks was also recorded using the Techsmith Morae software package. Morae records both video and audio, so in addition to the Web-based interaction with the Long and Short Versions, student audio commentary was also recorded. Students were asked to "think out loud" as they used the versions of the guide so that the research team had a verbal explanation of why the students navigated as they did. 
Menu

\begin{tabular}{|l|}
\hline Home \\
\hline Getting started with research \\
\hline Find background information \\
\hline Find articles \\
\hline Find books and ebooks \\
\hline Demographics \& Statistics \\
\hline Evaluating what you find \\
\hline Literature reviews \\
\hline Citing Sources $\sqsubset$ \\
\hline
\end{tabular}

Site map

\section{Site map}

- Home

- Getting started with research
- The research process
- The publishing timeline
- Identifying and narrowing a topic
- Identifying search terms
- Broaden or narrow your search

- Find background information

- Find articles
- Find scholarly articles
- Find newspaper articles
- Things to consider when reading an article

- Find books and ebooks

- Specific books for Comm 430

- Demographics and statistics

- Evaluating what you find

- How to distinguish between types of periodicals

- The CAARP Test

- Literature reviews

- Citing sources

Fig. 1. Menu and site map for the first version of the COMM 430 guide.

Before beginning the experiment, participants were asked to sign an informed consent form and complete a background questionnaire which asked general information about demographic data and the student's prior familiarity with library resources and services. All participants were majoring in one of the different communications majors offered through the Elliott School.

Five of the ten participants responded that they had previously used a LibGuide. Although three of these five expressed mild confusion as to what a LibGuide is, each of these participants was satisfied that they had previously used one once they understood its definition. All five who had not previously used a LibGuide stated they did not understand what it is. Five of the participants had attended a librarian-led information literacy session over the course of their studies and/or been to the University Libraries reference desk to seek assistance.

After completing these steps, participants were informed that the purpose of the study was to evaluate one version of the LibGuide or the other. They were purposely not provided much information about the guides so that unbiased first impressions could be gathered. They were given an overview of the study and their scenario, which was relayed to them by the facilitator.

Partly drawing from Cobus-Kuo et al. (2013) as a model, five tasks designed to test the usability of each version of the guide were developed (see Appendix A). These tasks, identified as T1 through T5, were completed by all participants on both versions of the guide. They required participants to:
Menu

\begin{tabular}{|l|}
\hline Home \\
\hline Find articles \\
\hline Find books and ebooks \\
\hline Demographics \& Statistics \\
\hline
\end{tabular}

Site map

\begin{tabular}{|c|}
\hline Site map \\
\hline $\begin{array}{l}\text { - Home } \\
\text { - Find articles } \\
\text { - Find scholarly articles } \\
\text { - Find newspaper articles } \\
\text { - Strategies for article searching, and reviewing and citing articles you find } \\
\text { - Find books and ebooks } \\
\text { - Specific books for Comm } 430 \\
\text { - Demographics and statistics }\end{array}$ \\
\hline
\end{tabular}

Fig. 2. Menu and site map for the second version of the COMM 430 guide. 


\section{Communication Research Strategies}

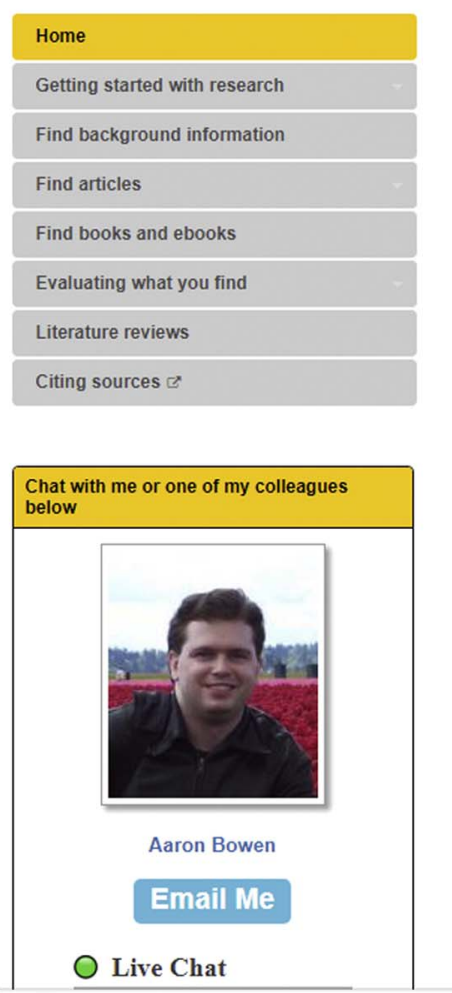

Live Chat

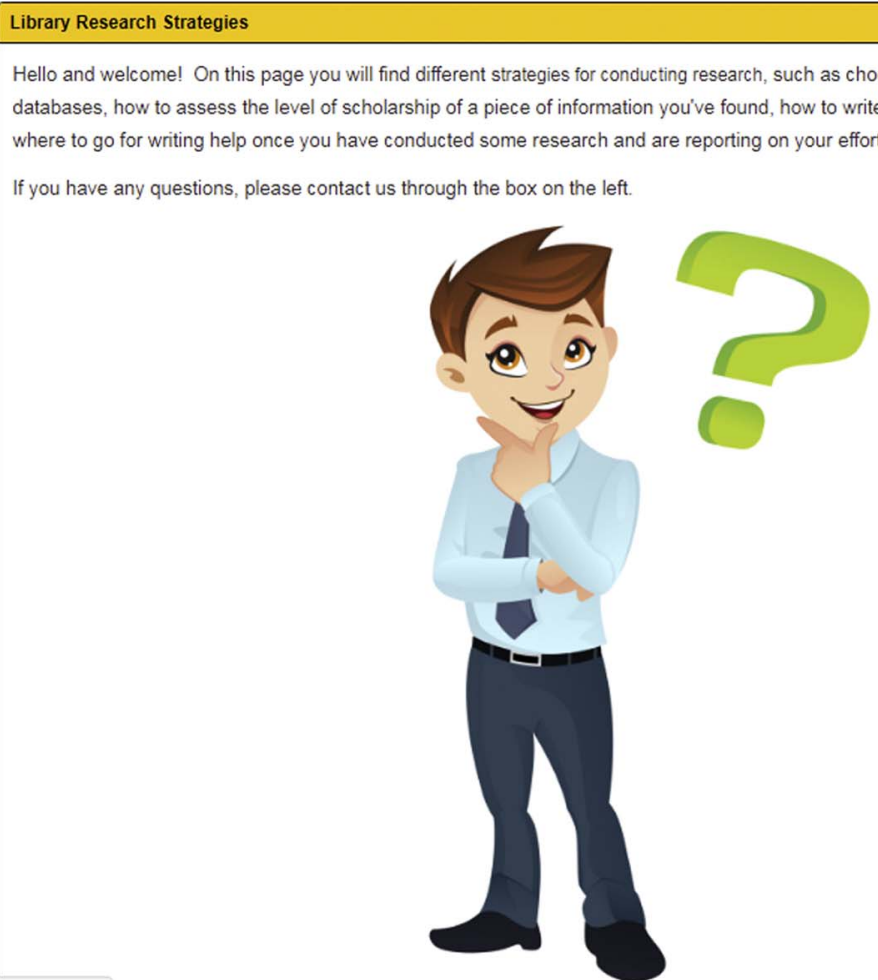

Fig. 3. Communication Research Strategies ancillary guide.

- Find how to identify a research topic (T1)

- Find what constitutes a scholarly article (T2)

- Find scholarly literature (T3)

- Find how to refine a search query (T4)

- Find information about constructing a literature review (T5)

Of these tasks, the third task can be completed through resources presented in both versions. The other four can be answered through resources presented in the Long Version and in the ancillary guide linked from the Short Version.

Across the two groups, the ten students were able to complete $100 \%$ of these tasks. After completing each task, participants were asked to rate its perceived ease/difficulty on a 7-point Likert-type scale $(1=$ very easy, $7=$ very difficult $)$ and confidence in task success on a 7-point Likert-type scale ( 1 = very confident, $7=$ not at all confident).

Each group viewed the other version of the guide after completing tasks using the initial version. However, as their experience with one version will have affected their ability to effectively and efficiently use the second, no within-subjects comparisons of the guides were made. This design allows a direct comparison of the two versions of the guide by comparing the results from the two testing groups, as well as the reactions of each member of the groups to the version they did not initially test.

Following the completion of all tasks, they were asked to complete the System Usability Scale (Brooke, 1996; see Appendix B), which assesses general user satisfaction and perceived usability of each guide and is summarized into a $0-100$ cumulative score. The word 'system' in the original System Usability Scale was replaced with 'website' for this study. Participants provided feedback on aspects they liked and disliked about each guide, as well as which guide they preferred.

\section{Phase One results}

Navigation by task: Long Version

Participant performance and subjective impressions were analyzed at the task level. All tables include mean values followed by the standard deviation (SD) in parentheses. Performance (first click, success rate in arriving at the correct destination, and task difficulty) is summarized by task in Table 1 . The easiest and most successful tasks were reported to be finding how to identify a research topic (T1), finding scholarly literature (T3), and finding information on constructing a literature review (T5). The most difficult and least successful tasks were: finding what constitutes a scholarly article (T2) and finding how to refine a search query (T4). First click data were gathered to determine how intuitive the site was for finding information. Typically, if there is consensus across participants as to where to click first, the navigation may be viewed as more intuitive for that specific task.

In addition to performance data, number of clicks and time on task was gathered to measure task efficiency. Table 2 shows that the tasks rated as more difficult and that were less successful also resulted in a higher number of clicks and longer completion times.

\section{Navigation by task: Short Version}

Performance (first clicks, success rate in arriving at the correct destination, and task difficulty) are summarized by task in Table 3. The easiest and most successful task was reported to be finding scholarly literature (T3). The most difficult and least successful tasks were: finding how to identify a research topic (T1), finding what constitutes a scholarly article (T2), finding how to refine a search query (T4), and finding information on constructing a literature review (T5).

In addition to performance data, number of clicks and time on task was gathered to measure task efficiency. Table 4 shows a summary of the number of clicks and time on task (min). As with the first version of 


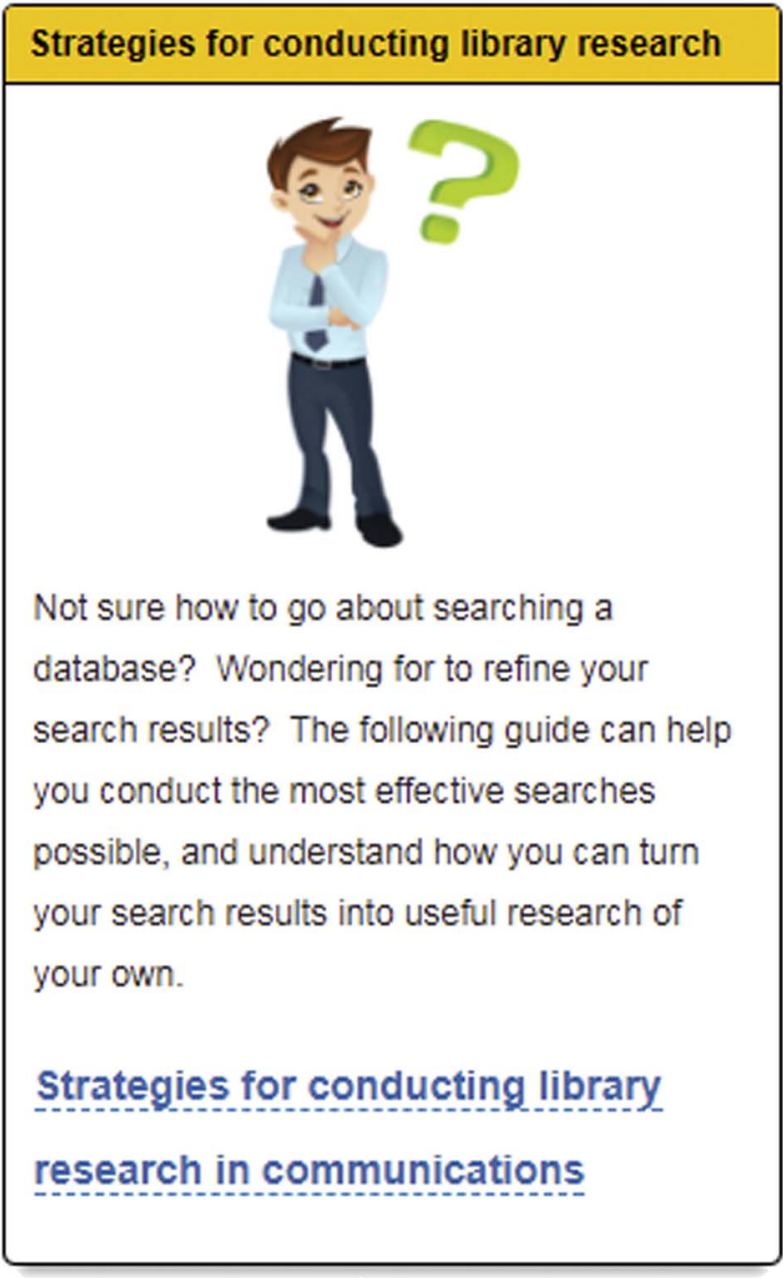

Fig. 4. Content box under both the scholarly and newspaper articles tabs.

the guide, the tasks rated as more difficult and that were less successful also resulted in a higher number of clicks and longer completion times.

Table 5 provides a comparison of the first version of the guide to the second using success ratings, overall preference, task difficulty ratings, and System Usability Scale ratings (SUS; see Appendix B). The SUS was used to measure perceived usability, with scores ranging from 0 to 100 . A larger number indicates a higher level of perceived usability, and with usable systems tend to produce scores in the 70-100 range. In
Table 2

Long Version number of clicks and completion time per task $(\mathrm{N}=5)$. The most difficult, least successful tasks are indicated by the use of bold font.

\begin{tabular}{|c|c|c|c|c|}
\hline Task & & $\begin{array}{l}\text { Optimal path } \\
\text { (\# clicks) }\end{array}$ & $\begin{array}{l}\text { \# of } \\
\text { clicks } \\
\text { (SD) }\end{array}$ & $\begin{array}{l}\text { Completion time in } \\
\text { seconds (SD) }\end{array}$ \\
\hline $\begin{array}{ll}\mathrm{T} 1 & \\
\mathrm{~F} \\
\mathrm{r}\end{array}$ & $\begin{array}{l}\text { Find how to identify a } \\
\text { research topic }\end{array}$ & 1 & $1.0(0.00)$ & $21.4(11.28)$ \\
\hline T2 & $\begin{array}{l}\text { Find what constitutes a } \\
\text { scholarly article }\end{array}$ & 1 & $\begin{array}{l}2.4 \\
(1.67)\end{array}$ & $77.8(94.96)$ \\
\hline T3 & Find scholarly literature & 1 & $1.2(0.45)$ & $20.4(9.76)$ \\
\hline $\begin{array}{r}\text { T4 } \\
\text { F } \\
\text { s }\end{array}$ & $\begin{array}{l}\text { Find how to refine a } \\
\text { search query }\end{array}$ & 1 & $\begin{array}{l}2.3 \\
(1.89)\end{array}$ & $74.2(55.11)$ \\
\hline $\begin{array}{l}\text { T5 } \\
\mathrm{F} \\
\mathrm{r} \\
\mathrm{r}\end{array}$ & $\begin{array}{l}\text { Find information on } \\
\text { constructing a literature } \\
\text { review }\end{array}$ & 1 & $\begin{array}{l}1.80 \\
(1.30)\end{array}$ & $40.6(35.58)$ \\
\hline
\end{tabular}

general, performance was better and participants were more positive about the Long Version.

After using either the Long or Short Version, participants were asked additional open-response questions on what they liked most and least about the guide (see Appendix B). In general, these comments centered on certain common themes. For example, students who tested the Long Version described the guide as easy to navigate, and said that they were easily guided through research process. They also found some navigation labeling to be unclear. Students who tested the Short Version described the guide as aesthetically pleasing, but also found the navigation labeling unclear and the navigation overall difficult to use due to the navigational transition between the course guide and ancillary guide.

The Long Version of the guide was deemed to have a high degree of usability in completing Tasks 1, 3, and 5 in that they each had $100 \%$ success rates and low average difficulty scores (indicating ease of use), as well as low numbers of clicks and minimal time needed to complete the task. The standard deviations further indicate a fairly small spread of deviation from the mean with regard to perceived ease of use.

Task 2 had a $60 \%$ completion rate, with an average difficulty rating of 3.2. Task 4 also had a $60 \%$ completion rate, with an average difficulty rating of 2.4. The standard deviations of average difficulty rating indicate a greater spread of levels of difficulty reported by students in completing these two tasks in comparison to Tasks 1,3 , and 5.

Reviewing student commentary from the usability sessions

Table 1

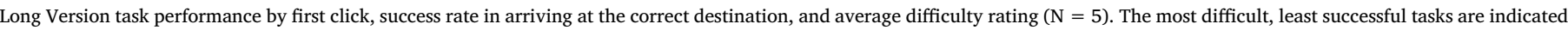
by the use of bold font.

\begin{tabular}{|c|c|c|c|}
\hline Task \# & First click & Success rate & Average difficulty rating (Mean, SD) \\
\hline $\mathrm{T} 1$ & Identifying and narrowing a topic $=5$ & $100 \%$ & $1.2(0.45)$ \\
\hline Find how to identify a research topic & & & \\
\hline T2 Find what constitutes a scholarly article & $\begin{array}{l}\text { How to Distinguish between types of Periodicals }=1 \\
\text { Evaluating what you find }=1 \\
\text { Things to consider when reading an article }=2 \\
\text { Find scholarly Articles }=1\end{array}$ & $60 \%$ & $3.2(2.59)$ \\
\hline T3 Find scholarly literature & $\begin{array}{l}\text { Find Scholarly Articles }=4 \\
\text { Find Articles }=1\end{array}$ & $100 \%$ & $1.2(0.45)$ \\
\hline T4 Find how to refine a search query & $\begin{array}{l}\text { Identifying and narrowing a topic }=2 \\
\text { Find scholarly Articles }=1 \\
\text { Broaden or narrow your search }=1 \\
\text { Identifying search terms }=1\end{array}$ & $60 \%$ & $2.4(2.61)$ \\
\hline T5 Find information about constructing a literature review & $\begin{array}{l}\text { Literature reviews }=3 \\
\text { Evaluating what you find }=1 \\
\text { Find background information }=1\end{array}$ & $100 \%$ & $1.0(0.00)$ \\
\hline
\end{tabular}

\footnotetext{
a 1 -Very easy and 7-Very difficult.
} 
Table 3

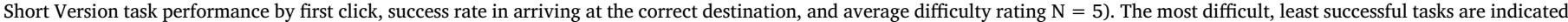
by the use of bold font.

\begin{tabular}{|c|c|c|c|c|c|}
\hline Tasl & & First click & Ancillary guide first click & Success rate & $\begin{array}{l}\text { Average difficulty rating } \\
(\text { Mean, SD) }\end{array}$ \\
\hline T1 & Find how to identify a research topic & $\begin{array}{l}\text { Strategies for... articles you find (Site } \\
\text { Map) }=1 \\
\text { Find scholarly articles }=1 \\
\text { Demographics \& statistics }=1 \\
\text { WSU Libraries Communication } \\
\text { research guide }=2\end{array}$ & $\begin{array}{l}\text { Identifying and narrowing a topic }=2 \\
\text { Identifying and narrowing a topic } \\
\text { (Site Map) }=1 \\
\text { Getting started with research (Site } \\
\text { Map) }=1\end{array}$ & $80 \%$ & $3.0(2.00)$ \\
\hline T2 & $\begin{array}{l}\text { Find what constitutes a scholarly } \\
\text { article }\end{array}$ & $\begin{array}{l}\text { Strategies for... articles you find }=1 \\
\text { Strategies for... articles you find (Site } \\
\text { Map) }=3 \\
\text { Find scholarly Articles (Site Map) }=1\end{array}$ & $\begin{array}{l}\text { Evaluate what you find }=1 \\
\text { Things to Consider... Scholarly } \\
\text { Article }=1 \\
\text { Find scholarly Articles (Site Map) = } 1 \\
\text { The research process }=1\end{array}$ & $20 \%$ & $3.4(1.82)$ \\
\hline $\mathrm{T} 3$ & Find scholarly literature & $\begin{array}{l}\text { Strategies for... articles you find }=1 \\
\text { Find scholarly Articles }=3 \\
\text { Find scholarly Articles }=1\end{array}$ & $\begin{array}{l}\text { Things to Consider When Reading a } \\
\text { Scholarly } \\
\text { Article }=1\end{array}$ & $80 \%$ & $2.4(1.67)$ \\
\hline T4 & Find how to refine a search query & $\begin{array}{l}\text { Strategies for... articles you find }=2 \\
\text { Strategies for... articles you find (Site } \\
\text { Map) }=1 \\
\text { WSU Libraries Communication } \\
\text { research guide }=1 \\
\text { Find Articles }=1\end{array}$ & $\begin{array}{l}\text { Broaden or narrow your search }=1 \\
\text { Broaden or narrow your search (Site } \\
\text { Map) }=2 \\
\text { Identifying search } \\
\text { terms }=1 \\
\text { Getting started with research }=1\end{array}$ & $80 \%$ & $3.2(2.28)$ \\
\hline T5 & $\begin{array}{l}\text { Find information on constructing a } \\
\text { literature review }\end{array}$ & $\begin{array}{l}\text { Strategies for... articles you find }=2 \\
\text { Strategies for... articles you find (Site } \\
\text { Map) }=1 \\
\text { WSU Libraries Communication } \\
\text { research guide }=1 \\
\text { Find scholarly Articles = } 1\end{array}$ & $\begin{array}{l}\text { Literature reviews }=2 \\
\text { Literature reviews (Site Map) }=1 \\
\text { Find background information }=1 \\
\text { Evaluating what } \\
\text { you find }=1\end{array}$ & $100 \%$ & $3.4(2.07)$ \\
\hline
\end{tabular}

a 1 -Very easy and 7-Very difficult.

Table 4

Short Version number of clicks and completion time per task $(\mathrm{N}=5)$. The most difficult, least successful tasks are indicated by the use of bold font.

\begin{tabular}{|c|c|c|c|c|}
\hline Task & & $\begin{array}{l}\text { Optimal path } \\
\text { (\# clicks) }\end{array}$ & $\begin{array}{l}\text { \# of } \\
\text { clicks } \\
\text { (SD) }\end{array}$ & $\begin{array}{l}\text { Completion time in } \\
\text { seconds (SD) }\end{array}$ \\
\hline $\mathrm{T} 1$ & $\begin{array}{l}\text { Find how to identify a } \\
\text { research topic }\end{array}$ & 2 & $\begin{array}{l}4.0 \\
(2.00)\end{array}$ & $46.0(12.75)$ \\
\hline T2 & $\begin{array}{l}\text { Find what constitutes a } \\
\text { scholarly article }\end{array}$ & 2 & $\begin{array}{l}6.0 \\
(2.24)\end{array}$ & $117.6(76.51)$ \\
\hline $\mathrm{T} 3$ & Find scholarly literature & 1 & $\begin{array}{l}2.6 \\
(2.51)\end{array}$ & $42.2(64.65)$ \\
\hline $\mathrm{T} 4$ & $\begin{array}{l}\text { Find how to refine a } \\
\text { search query }\end{array}$ & 2 & $\begin{array}{l}2.5 \\
(1.00)\end{array}$ & $68.0(46.76)$ \\
\hline T5 & $\begin{array}{l}\text { Find information about } \\
\text { constructing a literature } \\
\text { review }\end{array}$ & 2 & $\begin{array}{l}3.8 \\
(2.05)\end{array}$ & $58.0(41.04)$ \\
\hline
\end{tabular}

Table 5

Overall performance with the Long and Short Versions of the guide $(\mathrm{N}=10$ ) (Mean, SD)

\begin{tabular}{lll}
\hline & Long Version & Short Version \\
\hline Success rate & $84 \%$ & $72 \%$ \\
Preference & $80 \%$ & $20 \%$ \\
Task difficulty rating (overall) $^{\mathrm{a}}$ & $1.8(1.22)$ & $3.1(1.97)$ \\
Perceived usability $^{\mathrm{b}}$ & $76(10.55)$ & $55(28.50)$ \\
\hline
\end{tabular}

a 1 -Very easy and 7-Very difficult.

b 0-100 with higher scores indicating higher perceived usability.

regarding Task 2 indicates in a page placement usability issue on this version of the guide. One of the sub-tabs under the Find articles tab was titled "Things to consider when reading an article," and one of the subtabs under the Evaluating what you find tab was titled "How to distinguish between types of periodical." The disparate positioning of these sub-tabs was a source of confusion to students.

For the purposes of evaluating performance with Task 4, two subtabs under the Getting started with research tab were considered acceptable destinations. These sub-tabs were called "Identifying and narrowing a topic," and "Identifying search terms." Reviewing student commentary from the usability sessions regarding this task indicates that difficulties experienced by students stemmed largely from the terminology used in these tabs.

Examining the success rates and average perceived difficulty of each task among students testing the Short Version of the guide, only Task 5 was successfully completed by all students. Tasks 1,3 , and 4 were successfully completed by four out of five students, whereas only one of five completed Task 2 successfully. The average difficulty rating was above 3 for all tasks except Task 3, indicating significantly less confidence among students that they had completed tasks successfully than with students testing the Long Version. The standard deviations from the average perceived difficulty scores among these students in completing T1, T3, and T5 also reveal a greater spread of responses than those given by students testing the first version. This finding may offer a further indication of a lack of confidence among students testing the second version that they had correctly navigated the guide to complete these tasks. The standard deviations from the average perceived difficulty scores for T2 and T4, while lower than those reported by students testing the Long Version, still indicate a significant spread of responses. Overall, the spread of responses indicated by the standard deviations for all tasks in the Short Version may further indicate that it is less usable.

A comparison of click performance shows that students using the Short Version of the guide took more mouse clicks to complete all five tasks than students using the Long Version. As with the average perceived difficulty, the comparatively higher standard deviations for the click performance in the Short Version for all tasks except T4 indicate a greater spread in the number of clicks made by students testing it, which again may indicate a more difficult level of usability.

A comparison of completion time indicates that students using the 
Short Version completed all tasks slower than students using the first version except Task 4 . The standard deviations for completion time in both versions indicate a mixed spread of completion times, with neither version demonstrating a clearly faster ability to guide students to needed information. This may reflect broader usability challenges faced by students in using the two versions of the LibGuide, such as the terminology used in the menu options highlighted by the first version, and the ability to locate the ancillary guide from the second version.

Task 4 presents an interesting comparison between the two versions. Four out of five students testing the Short Version were able to successfully complete the task, whereas only three out of five testing the Long Version were successful. Students testing the Long Version took fewer mouse clicks to complete the task, but also took longer to complete it than students testing the Short Version. The Morae video of students completing T4 reveals the primary reason why neither version clearly outperformed the other to be difficulty among six of the ten students understanding what the task was asking them to do. Of these six, two were testing the Long Version, and four were testing the Short Version. One student apiece testing each version expressed confidence in the guide while explicitly stating that the wording of the question confused them. The audio commentary and navigational behavior of three students testing the Short Version revealed the bridge from the course guide to the auxiliary guide contributed to their confusion regarding the question. One student in particular said that this transition "felt like a process to get through just to fine what I needed to," and that she felt completing the task "would have been so much easier if it [the auxiliary guide content] was over here [on the course guide] in the first place."

The results from Phase One overall indicate a student preference for a longer-form navigation menu. Students specifically had an easier time completing T1, T3, and T5 with the Long Version. Students testing the Short Version had an easier time completing T3 in comparison to the other tasks, but still struggled to complete it in comparison to students completing the same task with the Long Version. Students testing both versions experienced difficulty with $\mathrm{T} 2$ and $\mathrm{T} 4$, but students testing the Long Version experienced less difficulty with T2 than students testing the Short Version. While by some measures students had an easier time with T4 in the Short Version, students testing both versions experienced difficulty understanding the task, partly due to the task's wording, and partly due to the navigational architecture of the Short Version of the guide. This finding offers a significant indication that students did not perceive the bridge from the Short Version's navigation menu to the instructional content that would help them complete tasks to be seamless. Instead, they seemed to find this transition more difficult with a shorter navigation menu than they did with a longer one.

Even with this initial understanding of student preference, the research team saw value in checking this finding against an additional sample of other students in the class, thus leading to the testing conducted in Phase two of the experiment.

\section{Phase Two methodology}

\section{Participants, materials, and procedure}

Fourteen participants (female $=12$, male $=2$ ) were recruited via email from the same Fall 2016 COMM 430 class that included the Phase One participants. There was no overlap between students who participated in either phase.

A between-groups single-factor design was again used with participants randomly assigned to one of two groups - one group testing the Long Version, and the other testing the Short Version. Participating in this testing, while being voluntary, was one of several activities a student could use to fulfill course requirements.

For this phase, students completed their testing online through the Treejack software package. Students viewed an informed consent message at the beginning of this testing, and then gave informed consent by continuing into Treejack. From here, students were given a task, and asked to surf their way through the navigational schematic to indicate where they believe they would find information that would help them complete the task.

As Treejack cannot test a dual navigation system such as the Short Version of the guide paired with the ancillary Communication Research Strategies guide, the second group only tested the guide up to the point that it branched off to the ancillary guide. This condition precluded the ability to test the number of clicks students took to arrive at their ultimate destination in relation to the optimal number of clicks to the "correct" page in the second version. As such, data on the total number of clicks students made is not included in Phase Two testing, though data on their first clicks is. This phase also did not make use of the 7point Likert-type scale or the System Usability Scale, and did not involve gathering student reactions to the version of the guide they did not initially test.

While the testing done through Treejack was less in-depth than that conducted at SURL, it allowed the research team to further test the findings from Phase One against a larger sample of class participants. This additional testing allowed the research team to more closely evaluate the usability of the guide's navigation, and other usability issues that stem from the guides' navigational elements. It also allowed the research team to hear from a strong majority of class members (73\%) on one version or the other of the guide.

Participants completed the Phase Two testing on their own computers. They were asked the same demographic questions as the Phase One testers. All fourteen participants in Phase Two were majoring in one of the different communications majors offered through the Elliott School, with one double majoring in Integrated Marketing Communications and Sociology. Two responded that they had used a LibGuide before, and the rest either responded they had not or expressed confusion as to what a guide is. Four had attended a librarianled information literacy session and/or visited the reference desk.

The Phase Two testing asked students to complete the same five usability tasks the Phase One testers completed. Instructions presented to students through the software informed them that they would be asked to look through the pages presented in the navigation menu and identify which page they thought would offer information most appropriate to completing the task. Across the two groups, all fourteen students were able to complete $100 \%$ of these tasks.

\section{Phase Two results}

\section{Navigation by task: long version}

In this version, four out of the seven students ( $57 \%$ in each case) were able to successfully complete tasks one, three, and five. Only one of the seven was indirectly successful in completing task four, and none were successful with task two. These findings are in line with the Phase One findings, which identified tasks two and four as the ones where students experienced the most difficulty (see Table 6).

\section{Navigation by task: short version}

In this version, none of the five tasks saw more than three correct responses, and Tasks 1, 2, and 4 had only one correct response apiece (see Table 7).

First clicks varied more significantly than they did among testers of the Long Version, betraying greater confusion regarding where to click to accomplish the task. This added confusion may be due to the shortened menu, which, by extension, contained fewer descriptors for the function of the different pages on the guide. By extension, this variation in first clicks may reveal the Short Version's navigation to not create the seamless path to instructional content needed to ensure the usability of this architectural design.

Furthermore, completion time across all five tasks was uniformly 
Table 6

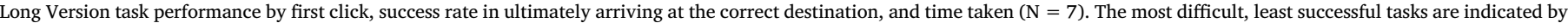
the use of bold font.

\begin{tabular}{|c|c|c|c|}
\hline Task \# & First click & Success rate & Time taken (seconds) \\
\hline T1 Find how to identify a research topic & $\begin{array}{l}\text { Getting started with research }=4 \\
\text { Find articles }=3\end{array}$ & $57 \%$ & 36.91 \\
\hline T2 Find what constitutes a scholarly article & $\begin{array}{l}\text { Getting started with research }=3 \\
\text { Find articles }=4\end{array}$ & $0 \%$ & 12.44 \\
\hline T3 Find scholarly literature & $\begin{array}{l}\text { Find Articles }=3 \\
\text { Find books and ebooks }=2 \\
\text { Evaluating what you find }=1\end{array}$ & $57 \%$ & 23.81 \\
\hline $\begin{array}{l}\text { T4 Find how to refine a search query } \\
\text { Fin }\end{array}$ & $\begin{array}{l}\text { Find background information }=2 \\
\text { Find books and ebooks }=1 \\
\text { Demographics and statistics }=2 \\
\text { Evaluating what you find }=2\end{array}$ & $14 \%$ & 16.06 \\
\hline T5 Find information about constructing a literature review & $\begin{array}{l}\text { Find articles }=1 \\
\text { Evaluating what you find }=2 \\
\text { Literature reviews }=4\end{array}$ & $57 \%$ & 14.26 \\
\hline
\end{tabular}

Table 7

Short Version task performance by first click, success rate in ultimately arriving at the correct destination, and time taken $(\mathrm{N}=7)$. The most difficult, least successful tasks are indicated by the use of bold font.

\begin{tabular}{|c|c|c|c|c|}
\hline Task & & First click & Success rate & $\begin{array}{l}\text { Time taken } \\
\text { (seconds) }\end{array}$ \\
\hline $\mathrm{T} 1$ & $\begin{array}{l}\text { Find how to identify } \\
\text { a research topic }\end{array}$ & $\begin{array}{l}\text { Find articles }=5 \\
\text { Find books and } \\
\text { ebooks: } 2\end{array}$ & $14 \%$ & 20.95 \\
\hline $\mathrm{T} 2$ & $\begin{array}{l}\text { Find what constitutes } \\
\text { a scholarly article }\end{array}$ & $\begin{array}{l}\text { Home }=1 \\
\text { Find articles }=6\end{array}$ & $14 \%$ & 8.21 \\
\hline $\mathrm{T} 3$ & $\begin{array}{l}\text { Find scholarly } \\
\text { literature }\end{array}$ & $\begin{array}{l}\text { Home }=1 \\
\text { Find Articles }=3 \\
\text { Find books and } \\
\text { ebooks }=2 \\
\text { Demographics and } \\
\text { statistics = } 1\end{array}$ & $43 \%$ & 12.83 \\
\hline $\mathrm{T} 4$ & $\begin{array}{l}\text { Find how to refine a } \\
\text { search query }\end{array}$ & $\begin{array}{l}\text { Home }=1 \\
\text { Find Articles = } 1 \\
\text { Find books and } \\
\text { ebooks }=1 \\
\text { Demographics and } \\
\text { statistics }=4\end{array}$ & $14 \%$ & 13.68 \\
\hline T5 & $\begin{array}{l}\text { Find information about } \\
\text { constructing a } \\
\text { literature review }\end{array}$ & $\begin{array}{l}\text { Home }=2 \\
\text { Find Articles }=3 \\
\text { Demographics and } \\
\text { statistics }=2\end{array}$ & $43 \%$ & 10.01 \\
\hline
\end{tabular}

faster than task completion time in the Long Version. One possible explanation for this finding is that, as there were fewer menu options to read, students spent less time reading them before deciding which page of the guide was most likely to help them accomplish the task.

The combination of faster response times with apparent confusion regarding where to click to accomplish the tasks are likely contributors to the overall poorer performance of the Short Version, with students experiencing the most difficulty with Tasks 1,2 , and 4 . This finding is similar to the Phase One findings, which identified Tasks 1, 2, 4, and 5 as the most difficult.

\section{Usability modifications to the course guide}

Though less robust and rich in terms of the data collected, Phase Two's findings support those of Phase One. In Phase Two, students using the Short Version experienced a greater challenge in addressing Task 1, and to a lesser extent Task 5 than students using the first version. Tasks 2 and 4 were comparatively challenging for students using both versions, whereas Task 3 posed the smallest usability challenge in each.

These results, combined with the Phase One findings, demonstrate the Long Version of the guide in each phase to be more usable to students in the class. Furthermore, they support certain revisions to improve the overall usability of the guide. Based upon the testing results, the Long Version served as the template on which the final COMM 430 course guide was built.

The final guide included simple adjustments to the placements and terminology of guide tabs, as well as some revision of content and the elimination of the ancillary guide:

- The titles of the Identifying and narrowing a topic and Identifying search terms tabs have been changed to Defining your topic and crafting your research question, and Identifying search terms from your question.

- The content of the Defining your topic and crafting your research question tab has also been revised to better describe the process of moving from a nebulous idea for a research topic to formulating a research question asking something unknown about the topic.

- The Evaluating what you find tab has been changed to Evaluating scholarly information, and includes the subtabs for How to distinguish between types of journal articles, Things to consider when reading an article, and The CAARP Test. ${ }^{4}$

- Also, in response to student confusion regarding the meaning of the CAARP acronym, the subtab titled The CAARP Test was renamed to Critically evaluating articles \& other resources: The CAARP Test.

Fig. 5 shows the final configuration of the navigation menu and its corresponding site map:

\section{Limitations of the study and future research}

This study involved only one class which is taught only as a single section, and which had a small number of students. One of the study's strengths - the fact that it sampled students in one upper division undergraduate class to test the guide dedicated to that class - may also be a limiting factor in that it did not involve students outside the Communication field, or newly coming to the field. Study results may not be generalizable to other student populations or to other fields due to these factors.

This limitation naturally invites a research agenda focusing on usability tests of guides dedicated to larger classes, 100 or 200 level classes, and graduate classes conducted with students in these respective courses. Similar studies could be conducted involving comparisons of students from different classes within a department, from different departments, or even at different universities. The comparisons that can be made from identifying different parings of courses and asking students to evaluate guides dedicated to these courses should

\footnotetext{
${ }^{4}$ The CAARP Test is a modification of The CRAAP Test (Blakeslee, 2004).
} 


\begin{tabular}{|l|}
\hline \multicolumn{1}{|c|}{ Menu } \\
\hline Home \\
\hline Getting started with research \\
\hline Find background information \\
\hline Find articles \\
\hline Find books and ebooks \\
\hline Demographics \& Statistics \\
\hline Evaluating scholarly information \\
\hline Literature reviews \\
\hline Citing Sources $\longleftarrow$ \\
\hline
\end{tabular}

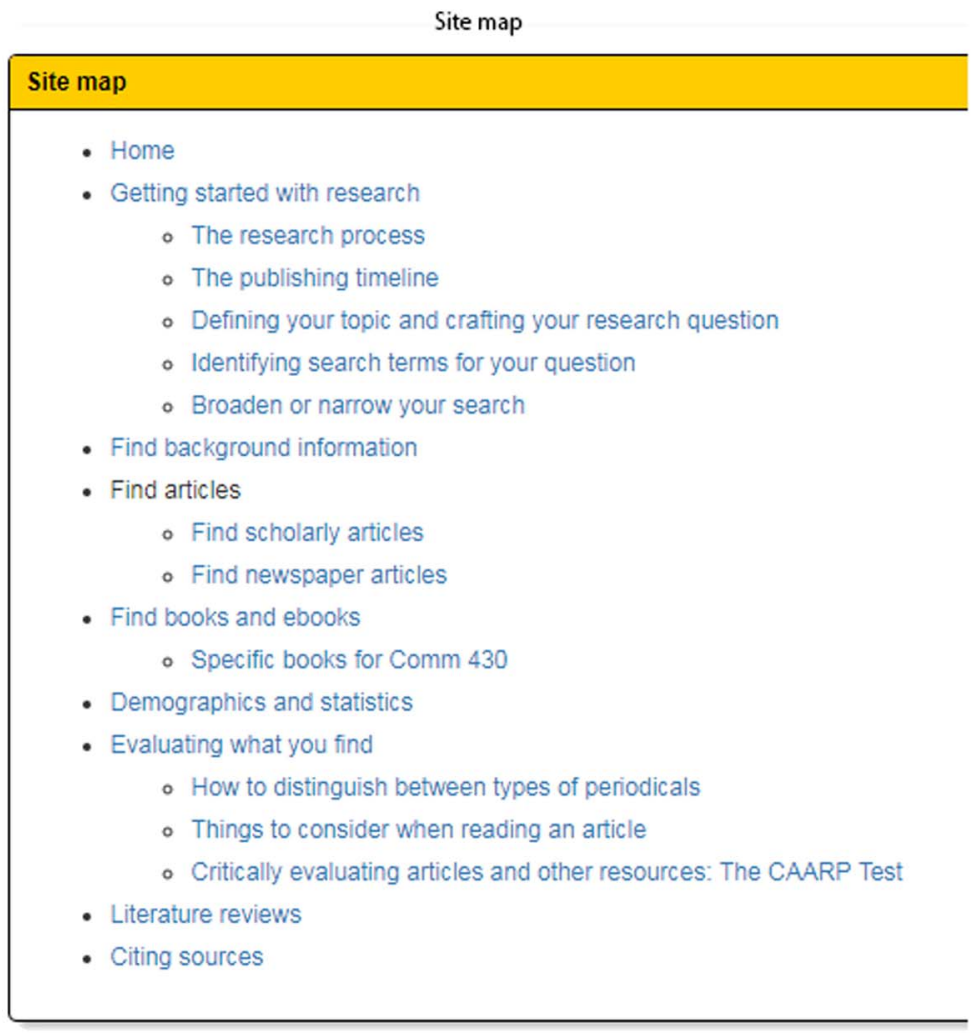

Fig. 5. Final menu and site map for the COMM 430 guide.

yield a robust, holistic picture of how students use course guides at different stages of their educational programs.

\section{Conclusion}

Despite some positive comments about the simplicity and visual appeal of the navigation menu in the Short Version of the guide, overall students preferred the Long Version and rated it as easier to use. Students commented that both guides provided useful information for guiding them through the research process. While students using both versions of the guide experienced some difficulty determining which sections would have information necessary for the tasks they sought to accomplish, this issue was more acute with students using the Short Version. The findability of the ancillary guide from this version was the main contributor to these difficulties, though other factors such as the labels describing guide pages and the placement of certain pages within the guides factored into usability difficulties as well.

These findings led to the implementation of a revised course guide derived from the Long Version. Furthermore, they can help foster informed decisions regarding the design and usability of future guides at WSU and at other universities. As librarians have an interest in designing guides that both center on student research needs and minimize the level of cognition required to understand a guide, this article's findings will be of value when developing the architecture, placement, and labeling of content in guide navigation. It offers an understanding of how best to design navigational elements to maximize a guide's usefulness and value to students.

\section{Acknowledgement}

Thank you to Dr. Jeffrey Jarman and the students in his Fall 2016 COMM 430 class.

This research did not receive any specific grant from funding agencies in the public, commercial, or not-for-profit sectors.
Appendix A. User tasks and additional questions

Tasks

1. As part of your coursework, you are asked to write a 5-8 page paper on a topic of your choosing. Your instructions state that you must include a literature review in the paper, and directs you to the library research guide in order to complete this assignment. Starting on the guide without an immediate idea of what your research topic might be, how would you go about identifying and narrowing a topic?

Desired outcomes:

- First version: student finds the Identifying and narrowing a topic page.

- Second version: student finds the content box linking to the ancillary guide under the scholarly or newspaper articles tabs (Phase One only), or the Strategies for searching for, evaluating, and citing articles you find page.

2. Your assignment instructions say that the literature review in your paper must be completed using scholarly journal articles. If you are unsure what makes an article scholarly as opposed to something else, how would you go about learning what makes an article scholarly? (If you are familiar with what makes an article scholarly vs. non-scholarly, show what you would do to answer the question anyway).

Desired outcomes:

- First version: student finds the How to distinguish between types of periodicals and/or CAARP Test pages.

- Second version: student finds the content box linking to the ancillary guide under the scholarly or newspaper articles tabs (Phase One only), or the Strategies for searching for, evaluating, and citing 
articles you find page.

3. Having identified a possible topic (and narrowed it down if needed), you are interested in what scholarly literature has been written on this topic. How would you go about finding scholarly literature on the topic of your choosing? (Please note that some scholarly literature may also be described as peer-reviewed literature - the two terms are roughly synonymous with each other).

Desired outcomes:

- First version: student finds the Find scholarly articles and/or Specific books for COMM 430 pages.

- Second version: student finds the Find scholarly articles and/or Specific books for COMM 430 pages.

4. Your initial search for scholarly literature yields some possibly useful articles, but overall you aren't satisfied with your search results. How would you learn to craft your searches to better target the type of literature you hope to find?

Desired outcomes:

- First version: student finds the Identifying search terms and/or Broaden or narrow your search pages

- Second version: student finds the content box linking to the ancillary guide under the scholarly or newspaper articles tabs (Phase One only), or the Strategies for searching for, evaluating, and citing articles you find page.

5. Your subsequent search attempts yield better-targeted literature, and you decide to make this your research topic. Where would you look to find an explanation of how to put multiple scholarly articles you have identified into a literature review?

Desired outcomes:

- First version: student finds the Literature reviews page.

- Second version: student finds the content box linking to the ancillary guide under the scholarly or newspaper articles tabs (Phase One only), or the Strategies for searching for, evaluating, and citing articles you find page.

Please note: the "Strategies for searching for, evaluating, and citing articles you find" page on the second version of the guide redirects a student to the ancillary Communication Research Strategies guide, which includes pages on identifying and narrowing a topic, identifying keywords, broadening or narrowing a topic, distinguishing between types of periodicals, and writing literature reviews.

Post-task questions (Phase One only)

How easy or difficult was this task?

1 - Very EASY

2

3

4

5

7 - Very Difficult

How confident are you that you completed this task successfully?

1 - Very Confident

2

3

4

5

6

7 - Not at all Confident

\section{Additional questions (Phase One only)}

1. Do you have any comments about this site in general? (After completing tasks using first website.)

2. Did you notice anything different about the second website?

3. Which website did you prefer? Why?

\section{Appendix B. Phase one post-test questionnaires}

System Usability Scale (Brooke, 1996)

All items had a response scale of $1=$ Strongly Disagree to $5=$ Strongly Agree.

1. I think I would want to use this website frequently.

2. I found the website unnecessarily complex.

3. I thought the website was easy to use.

4. I thought that I would need the support of a technical person to be able to use this website.

5. I felt the functionality of the website was well integrated.

6. I thought there was too much inconsistency on this website.

7. I would imagine that most people would learn to use this website very quickly.

8. I found the website very cumbersome/awkward to use.

9. I felt very confident using the website.

10. I needed to learn a lot of things before I could get going with this website.

\section{Post-test questions}

1. What did you like the BEST about this website? (open-ended)

2. What did you like the LEAST about this website? (open-ended)

\section{References}

Adebonojo, L. G. (2010). LibGuides: Customizing subject guides for individual courses. College \& Undergraduate Libraries, 17(4), 398-412. http://dx.doi.org/10.1080/ 10691316.2010 .525426$.

Adebonojo, L. G., \& Campbell, K. (2017). LibGuides to the rescue: The cure for the same old boring papers. College \& Undergraduate Libraries, 24(1), 51-64. http://dx.doi.org 10.1080/10691316.2015.1070703.

Allen, B. (1996). Information tasks: Toward a user-centered approach. San Diego, CA: Academic Press.

Allen, M. (2008). Promoting critical thinking skills in online information literacy in struction using a constructivist approach. College \& Undergraduate Libraries, 15(1/2), 21-38. http://dx.doi.org/10.1080/10691310802176780.

Almeida, N., \& Tidal, J. (2017). Mixed methods, not mixed messages: Improving LibGuides with student usability data. Evidence Based Library and Information Practice, 12(4), 62-77.

Alverson, J., Schwartz, J., Brunskill, A., \& Lefager (2015). Creating audience and environment-friendly research guides: Findings from a user study. Paper presented at the Association of College \& Research Libraries, Portland, ORhttp://via.library.depaul.edu/ lib_pubs $/ 7 /$.

Anderson, K. E., \& Still, J. M. (2013). Librarians' use of images on LibGuides and other social media platforms. Journal of Web Librarianship, 7(3), 272-291. http://dx.doi. org/10.1080/19322909.2013.812473.

Baker, R. L. (2014). Designing LibGuides as instructional tools for critical thinking and effective online learning. Journal of Library \& Information Services in Distance Learning, 8(3/4), 107-117. http://dx.doi.org/10.1080/1533290X.2014.944423.

Bazeley, J., \& Natale, J. (2014). Change as opportunity: Re-vamping LibGuides to better engage students. Paper presented at the Academic Library Association of Ohio Annual Conference, Sandusky, OHhttps://sc.lib.miamioh.edu/handle/2374.MIA/5163.

Blakeslee, S. (2004). The CRAAP Test. LOEX Quarterly, 31(3), 6-7. Retrieved from http:// commons.emich.edu/cgi/viewcontent.cgi? article $=1009 \&$ context $=$ loexquarterly .

Bowen, A. (2012). A LibGuides presence in a Blackboard environment. Reference Services Review, 40(3), 449-468. http://dx.doi.org/10.1108/00907321211254698.

Bowen, A. (2014). LibGuides and web-based library guides in comparison: Is there a pedagogical advantage? Journal of Web Librarianship, 8(2), 147-171. http://dx.doi. org/10.1080/19322909.2014.903709.

Brooke, J. (1996). SUS: A quick and dirty usability scale. In P. W. Jordan, B. Thomas, B. A Weerdmeester, \& I. L. McClelland (Eds.). Usability evaluation in industry (pp. 189194). London, UK: Taylor \& Francis.

Bruce, C. (1997). The seven faces of information literacy. Adelaide, Australia: Auslib Press.

Burrell, A., \& Sodan, A. C. (2006). Web interface navigation design: Which style of navigationlink menus do users prefer? Paper presented at the 22nd International Conference on Data Engineering Workshops, Atlanta, GA. 
Castro Gessner, G., Chandler, A., \& Wilcox, W. S. (2015). Are you reaching your audience? Reference Services Review, 43(3), 491-508. http://dx.doi.org/10.1108/RSR-022015-0010.

Chen, Y., Germain, C. A., \& Rorissa, A. (2011). Defining usability: How library practice differs from published research. Portal: Libraries and the Academy, 11(2), 599-628. Retrieved from https://muse.jhu.edu/article/428876.

Chiware, M. (2014). The efficacy of course-specific library guides to support essay writing at the University of Cape Town. South African Journal of Libraries \& Information Science, 80(2), 27-35. http://dx.doi.org/10.7553/80-2-1522.

Cobus-Kuo, L., Gilmour, R., \& Dickson, P. (2013). Bringing in the experts: Library research guide usability testing in a computer science class. Evidence Based Library \& Information Practice, 8(4), 43-59. Retrieved from https://journals.library.ualberta.ca/ eblip/index.php/EBLIP.

Collery, J., Collinge, N., \& O'Ceallaigh, M. (2016). Development of an academic integrity LibGuide. SCONUL Focus, 68, 68-71. Retrieved from https://www.sconul.ac.uk/ page/sconul-focus.

Conerton, K., \& Goldenstein, C. (2017). Making LibGuides work: Student interviews and usability tests. Internet Reference Services Quarterly, 22(1), 43-54. http://dx.doi.org/ 10.1080/10875301.2017.1290002.

Corbin, J., \& Karasmanis, S. (2009). Health sciences information literacy modules: Usability testing report. Retrieved from Bundoora, Australia: http://arrow.latrobe. edu.au:8080/vital/access/manager/Repository/latrobe:20690.

Courtois, M. P., Higgins, M. E., \& Kapur, A. (2005). Was this guide helpful? Users' perceptions of subject guides. Reference Services Review, 33(2), 188-196. http://dx.doi. org/10.1108/00907320510597381.

Dalton, M., \& Pan, R. (2014). Snakes or ladders? Evaluating a LibGuides pilot at UCD library. Journal of Academic Librarianship, 40(5), 515-520. http://dx.doi.org/10. 1016/j.acalib.2014.05.006.

DiSimio, T., \& Chrisagis, X. (2014). Rethinking out LibGuides to engage our students: Easy DIY LibGuides usability testing and redesign that works. Paper presented at the American Library Association of Ohio, Sandusky, OHhttp://corescholar.libraries.wright.edu/ul pub/168.

Dobbs, A. W., \& Sittler, R. L. (2016). Integrating LibGuides into library websites. Lanham, MD: Rowman \& Littlefield.

Dobbs, A. W., Sittler, R. L., \& Cook, D. (2013). Using LibGuides to enhance library services. Chicago, IL: American Library Association.

Ellis, D. (1989). A behavioral model for information retrieval system design. Journal of Documentation, 45(3), 171-212. Retrieved from http://www.emeraldinsight.com/ journal/jd.

Giullian, J. C., \& Zitser, E. A. (2015). Beyond LibGuides: The past, present, and future of online research guides. Slavic \& East European Information Resources, 16(4), 170-180. http://dx.doi.org/10.1080/15228886.2015.1094718.

Glassman, N. R., \& Sorensen, K. (2010). From pathfinders to subject guides: One Library's experience with LibGuides. Journal of Electronic Resources in Medical Libraries, 7(4), 281-291. http://dx.doi.org/10.1080/15424065.2010.529767.

Gonzalez, A. C., \& Westbrock, T. (2010). Reaching out with LibGuides: Establishing a working set of best practices. Journal of Library Administration, 50(5/6), 638-656. http://dx.doi.org/10.1080/01930826.2010.488941.

Grassian, E., LeMire, S., \& German, E. (2017). LibGuides for Instruction. Reference \& User Services Quarterly, 56(3), 162-167. Retrieved from https://doi.org/10.5860/rusq $56 n 3.162$.

Hemmig, W. (2005). Online pathfinders toward an experience-centered model. Reference Services Review, 33(1), 66-87 (doi:10.1108100907320510581397).

Hernandez, J. J., \& McKeen, L. (2015). Moving mountains. Online Searcher, 39(2), 16-21. Retrieved from http://www.infotoday.com/OnlineSearcher/.

Hintz, K., Farrar, P., Eshghi, S., Sobol, B., Naslund, J.-A., Lee, T., ... McCauley, A. (2010). Letting students take the lead: A user-centred approach to evaluating subject guides. Evidence Based Library \& Information Practice, 5(4), 39-52. Retrieved from https:// journals.library.ualberta.ca/eblip/index.php/EBLIP.

Hungerford, R., Ray, L., Tawatao, C., \& Ward, J. (2010). LibGuides usability testing. WA Retrieved from Seattle. https://digital.lib.washington.edu/researchworks/handle/ $1773 / 17101$.

Ingwersen, P. (1996). Cognitive perspectives of information retrieval interaction elements of a cognitive IR theory. Journal of Documentation, 52(1), 3-50. http://dx.doi.org/10. $1108 /$ eb026960.

International Standards Organization (1998). ISO 9241-11:1998. Geneva, Switzerland: International Standards Organization.

Jackson, R. (2007). Cognitive development. Reference \& User Services Quarterly, 46(4), 28-32. Retrieved from https://journals.ala.org/index.php/rusq.

Jackson, R. (2008). Information literacy and its relationship to cognitive development and reflective judgment. New Directions for Teaching \& Learning, 2008(114), 47-61. http://dx.doi.org/10.1002/tl.316.

Johnson, W. G. (2007). The application of learning theory to information literacy. College \& Undergraduate Libraries, 14(4), 103-120. http://dx.doi.org/10.1080/ 10691310802128435
Kuhlthau, C. C. (1991). Inside the search process: Information seeking from the user's perspective. Journal of the American Society for Information Science, 42(5), 361-371. Retrieved from http://onlinelibrary.wiley.com/journal/10.1002/(ISSN)2330-1643.

Kuhlthau, C. C. (2004). Seeking meaning: A process approach to library and information services. Westport, CT: Libraries Unlimited.

Liébert, A., \& Coig, A. (2015). Créer des « guides sujets » avec LibGuides. Le nouveau site web du SCD Paris Descartes. I2D: Information, Données \& Documents, 2, 12-15. Retrieved from https://www.cairn.info/revue-i2d-information-donnees-etdocuments.htm.

Little, J. J. (2010). Cognitive load theory and library research guides. Internet Reference Services Quarterly, 15(1), 53-63. http://dx.doi.org/10.1080/10875300903530199.

Mahaffy, M. (2012). Student use of library research guides following library instruction. Communications in Information Literacy, 6(2), 202-213. Retrieved from http://www. comminfolit.org/index.php?journal = cil.

Markman, K. M. (2016). Reimagining Harvard's LibGuides. Paper presented at computers in libraries, Washington, D.Cwww.krismarkman.com/wp-content/uploads/2010/05/ CIL_Markman_v2.pdf.

McMullin, R., \& Hutton, J. (2010). Web subject guides: Virtual connections across the university community. Journal of Library Administration, 50(7/8), 789-797. http://dx doi.org/10.1080/01930826.2010.488972.

Miner, J., \& Alexander, R. (2010). LibGuides in political science: Improving student access, research, and information literacy. Journal of Information Literacy, 4(1), 40-54. Retrieved from https://ojs.lboro.ac.uk/JIL/index.

Murphy, S. A., \& Black, E. L. (2013). Embedding guides where students learn: Do design choices and librarian behavior make a difference? Journal of Academic Librarianship, 39(6), 528-534. http://dx.doi.org/10.1016/j.acalib.2013.06.007.

Oelschlegel, S., Luhrs, J., \& Lindsay, J. M. (2017). Transitioning technologies: Pathfinder of the future. Journal of Consumer Health on the Internet, 21(1), 1-10. http://dx.doi. org/10.1080/15398285.2017.1279920.

Ouellette, D. (2011). Subject guides in academic libraries: A user-centered study of uses and perceptions. The Canadian Journal of Information and Library Science, 35(4), 436-451. http://dx.doi.org/10.1353/ils.2011.0024.

Pickens, K. E. (2017). Applying cognitive load theory principles to library instructional guidance. Journal of Library \& Information Services in Distance Learning, 11(1/2), 50-58. http://dx.doi.org/10.1080/1533290X.2016.1226576.

Pittsley, K. A., \& Memmott, S. (2012). Improving independent student navigation of complex educational web sites: An analysis of two navigation design changes in LibGuides. Information Technology \& Libraries, 31(3), 52-64. Retrieved from https:// ejournals.bc.edu/ojs/index.php/ital/index.

Quintel, D. F. (2016). LibGuides and usability: What our users want. Computers in Libraries, 36(1), 4-8. Retrieved from http://www.infotoday.com/cilmag/.

Reeb, B., \& Gibbons, S. (2004). Students, librarians, and subject guides: Improving a poor rate of return. Portal: Libraries \& the Academy, 4(1), 123-130. Retrieved from https:// muse.jhu.edu/article/51307.

Saracevic, T. (1996). Modeling interaction and information retrieval (IR): A review and proposal. Paper presented at the 59th ASIS Annual Meeting, Baltimore, MD.

Sinkinson, C., Alexander, S., Hicks, A., \& Kahn, M. (2012). Guiding design: Exposing librarian and student mental models of research guides. Portal: Libraries and the Academy, 12(1), Retrieved from https://muse.jhu.edu/article/463980.

Sittler, R., \& Dobbs, A. (2016). Innovative LibGuides applications : Real world examples. Lanham, NJ: Rowman \& Littlefield.

Sonsteby, A., \& Dejonghe, J. (2013). Usability testing, user-centered design, and LibGuides subject guides: A case study. Journal of Web Librarianship, 7(1), 83-94. http://dx.doi.org/10.1080/19322909.2013.747366.

Staley, S. M. (2007). Academic subject guides: A case study of use at San José state university. College \& Research Libraries, 68(2), 119-139. http://dx.doi.org/10.5860/ crl.68.2.119.

Stitz, T., Laster, S., Bove, F. J., \& Wise, C. (2011). A path to providing user-centered subject guides. Internet Reference Services Quarterly, 16(4), 183-198. http://dx.doi. org/10.1080/10875301.2011.621819.

Tchangalova, N., \& Feigley, A. (2008). Subject guides: Putting a new spin on an old concept. Electronic Journal of Academic \& Special Librarianship, 9(3), Retrieved from http://southernlibrarianship.icaap.org/.

Tempelman-Kluit, N. (2006). Multimedia learning theories and online instruction. College \& Research Libraries, 67(4), 364-369. http://dx.doi.org/10.5860/crl.67.4.364.

Thorngate, S., \& Hoden, A. (2017). Exploratory usability testing of user interface options in LibGuides 2. College \& Research Libraries, 78(6), http://dx.doi.org/10.5860/crl.78. 6.844.

Turner, D., \& Myer, S. (2012). Evaluating a new eletronic service using mixed methods. $4^{\text {th }}$ international conference on qualitative and quantative methods in libraries, Limerick, Irelandhttp://tees.openrepository.com/tees/handle/10149/228811.

Vileno, L. (2010). Testing the usability of two online research guides. Partnership: The Canadian Journal of Library \& Information Practice \& Research, 5(2), 1-21. Retrieved from https://journal.lib.uoguelph.ca/index.php/perj/\#.WhTIFXlrxQI. 